\title{
Efektifitas Metode Funcalistung Dalam Menumbuhkan Minat dan Kegemaran Mengenal Huruf Dan Angka (Studi Kualitatif Di Kelompok B TK Cahaya Indonesia Cimahi )
}

\author{
Ika Rustika Zainah \\ e-mail : rustika77@yahoo.com
}

\begin{abstract}
Abstrak. Pendidikan Anak Usia Dini (PAUD) adalah suatu upaya pembinaan yang ditujukan kepada anak sejak lahir sampai dengan usia enam tahun yang dilakukan melalui pemberian rangsangan pendidikan untuk membantu pertumbuhan dan perkembangan jasmani dan rohani agar anak memiliki kesiapan dalam memasuki pendidikan lebih lanjut. Aspek kognitif adalah salah satu kompetensi dasar yang merupakan aspek yang harus dikembangkan pada usia 5-6 tahun dikarenakan hal tersebut merupakan dasar dari kemampuan prabaca dan prahitung yang mempunyai peran penting dalam melanjutkan ke jenjang Sekolah dasar (SD). Kenyataan di lapangan para orang tua murid PAUD mempunyai tuntutan kepada para pengelola dan guru PAUD untuk dapat mengajarkan materi membaca, menulis, berhitung pada anak anaknya. Hal ini menjadi sebuah tantangan kepada guru PAUD untuk menguasai metode yang tepat dalam menyampaikan materi membaca dan berhitung yang menyenangkan buat anak sehingga anak tidak merasa terpaksa dalam mengikuti pembelajaran tersebut. Untuk itu maka peneliti bermaksud untuk melakukan penelitian tentang sejauh mana efektifitas metode Funcalistung dalam menumbuhkan minat dan kegemaran mengenal huruf dan angka di kelompok TK Cahaya Indonesia. Penelitian ini merupakan penelitian deskriftif dengan menggunakan pendekatan kualitatif. Peneliti berupaya mendeskripsikan hasil dari observasi dalam hal strategi khusus, peran guru, media pembelajaran dan suasana yang tercipta ketika kegiatan belajar yang menggunakan metode Funcalistung di kelompok B TK cahaya Indonesia, serta mewawancara kepala sekolah, guru kelompok B dan Orangtua siswa. Hasil penelitian : pertama: strategi khusus yang digunakan adalah dengan menggunakan materi yang sesuai dengan tujuan, kedua: peran guru yang berpartisipasi aktif, ketiga: media yang bervariatif dengan trik-trik khusus dalam penggunaanya, keempat: menciptakan suasana siswa yang antusias dalam mengikuti pembelajaran. Implementasi : pertama: guru dapat menerapkan strategi khusus dalam memotivasi siswa, kedua: guru lebih meningkatkan kemampuan dalam membuat perencanaan dan strategi pembelajaran serta berpartisipasi aktif dalam mengajar, ketiga: media pembelajaran dibuat semenarik mungkin, variatif dalam menggunakannya serta dapat dimainkan oleh siswa, keempat: menciptakan suasana pembelajaran yang asyik dan menyenangkan dan siswa pun antusias dalam mengikuti pembelajaran tersebut.
\end{abstract}

\section{Kata kunci : Metodik Funcalistung-menumbuhkan minat dan kegemaran mengenal huruf dan angka.}

Abstract. Early Childhood Education (ECD) is a development effort aimed at children from birth to the age of six, which is done through the provision of educational stimulus to help the growth and development of children physically and mentally in order to have the readiness to enter further education. The cognitive aspect is one of the basic competence is an aspect that should be developed at the age of 5-6 years because it is the basis of pre-reading and pre-count ability which have an important role in continuing to pursue elementary school (SD). In reality the early childhood parents have a claim to the managers and early childhood teachers to be able to teach the material to read, write, count on their children. This becomes a challenge for early childhood teachers to use the proper method in presenting the material reading and math fun for children so that children do not feel compelled to follow the learning. To that end, the researchers intend to conduct research on the extent to which the effectiveness of the method Funcalistung in growing interest and fondness recognize letters and numbers in groups of Cahaya Indonesia kindergarten. This study is a descriptive study using a qualitative approach. Researchers attempt to describe the results of observations in terms of specific strategies, the role of teachers, instructional media and the atmosphere created when learning activities using Funcalistung in group B at Cahaya Indonesia kindergarten, and interviewed principals, teachers and parents group B students. Result: The first: a special strategy is to use the material in accordance with the objectives, both: the role of teachers who participate actively, third: the media varied with special tricks in use, the fourth: creating an atmosphere of enthusiastic students in the following study. Implementation: The first: the teacher can implement specific strategies to motivate students, second: more teachers improve their skills in planning and learning strategies as well as actively participate in the teaching, the third: learning media made it interesting, varied in use and can be played by students, fourth: creating a learning environment that is fun and enjoyable and students were enthusiastic in participating in the study.

Keywords: methodical Funcalistung - foster interest and fondness recognize letters and numbers. 


\section{Pendahuluan}

Undang-undang Nomor 20 tahun 2003 tentang Sistem Pendidikan Nasional memberikan dasar hukum untuk membangun pendidikan nasional dengan menerapkan prinsip demokrasi, desentralisasi, otonomi, keadilan dan menjunjung tinggi hak asasi manusia. Oleh sebab itu, semua lapisan masyarakat yang terkait dengan pendidikan, baik secara langsung maupun tidak langsung, baik pada pendidikan formal, nonformal ataupun informal harus mampu mengembangkan kemampuan dan membentuk watak serta peradaban bangsa yang bermartabat.

Undang-undang Nomor 20

Tahun 2003 tentang Sistem Pendidikan Nasional Pasal 1 angka 14 menyatakan bahwa Pendidikan Anak Usia Dini (PAUD) adalah suatu upaya pembinaan yang ditujukan kepada anak sejak lahir sampai dengan usia enam tahun yang dilakukan melalui pemberian rangsangan pendidikan untuk membantu pertumbuhan dan perkembangan jasmani dan rohani agar anak memiliki kesiapan dalam memasuki pendidikan lebih lanjut. Dalam perkembangannya, masyarakat telah menunjukkan kepedulian terhadap masalah pendidikan, pengasuhan, dan perlindungan anak usia dini untuk usia 0 sampai dengan 6 tahun dengan berbagai jenis layanan sesuai dengan kondisi dan kemampuan yang ada, baik dalam jalur pendidikan formal maupun non formal. Penyelenggaraan PAUD jalur pendidikan formal berbentuk Taman Kanak-Kanak (TK)/Raudhatul Atfal (RA) dan bentuk lain yang sederajat, yang menggunakan program untuk anak usia $4-\leq 6$ tahun. Sedangkan penyelenggaraan PAUD jalur pendidikan nonformal berbentuk Taman Penitipan Anak (TPA) dan bentuk lain yang sederajat, yang menggunakan program untuk anak usia $0-<2$ tahun, $2-<4$ tahun, $4-\leq 6$ tahun dan Program Pengasuhan untuk anak usia $0-\leq 6$ tahun; Kelompok Bermain (KB) dan bentuk lain yang sederajat, menggunakan program untuk anak usia $2-<4$ tahun dan $4-\leq 6$ tahun.

Pendidikan anak usia dini mempunyai tujuan untuk menanamkan dan mengembangkan keimanan dan ketaqwaan (ketuhanan), menanamkan sikap disiplin, mengelola keterampilan tubuh termasuk gerakan-gerakan yang mengontrol gerakan tubuh, meningkatkan kecakapan anak yang merupakan kesanggupan anak untuk menunjukan sesuatu yang berkaitan dengan fisik dan mental serta melatih dan mengembankan kepekaan (sensitivitas) anak terhadap sesuatu.Menurut peraturan menteri pendidikan nasional no 58 tahun 2009 bahwa : Tingkat pencapaian perkembangan menggambarkan pertumbuhan dan perkembangan yang diharapkan dicapai anak pada rentang usia tertentu. Perkembangan anak yang dicapai merupakan integrasi aspek pemahaman nilai-nilai agama dan moral, fisik, kognitif, bahasa, dan sosialemosional.

Adapun dalam beberapa aspek perkembangan yang meupakan kompetensi dasar yang harus dikembangkan pada anak usia dini terdapat aspek perkembangan yang merupakan aspek yang sangat penting dikembangkan pada usia 5-6 tahun, yakni aspek kognitif yang menurut peraturan mentri pendidikan nasional no 58 tahun 2009 adalah sebagai berikut :

\section{Kognitif}

Huruf

Konsep Lambang Bilangan dan
a. Mengenal konsep bilangan 1 $-10$
b. Mencocokan bilangan dengan lambang bilangan
c. Mengenal berbagai macam huruf vokal dan konsonan

Perkembangan kognitif adalah kompetensi dasar yang harus di 
stimulasi semaksimal mungkin, terutama pada anak usia 5-6 tahun. Dikarenakan hal tersebut merupakan dasar dari kemampuan prabaca dan prahitung yang mempunyai peran penting dalam melanjutkan jenjang di SD.

Terkait dengan hal di atas, pada kenyataan di lapangan para orang tua murid Paud mempunyai tuntutan kepada para pengelola dan guru Paud untuk dapat mengajarkan materi membaca, menulis, berhitung pada anak anaknya. Sehingga mereka mempunyai harapan setelah mengikuti kegiatan belajar mengajar di jenjang Paud anak anak nya dapat membaca, menulis dan berhitung dengan lancar. Hal ini dikarnakan karna ternyata banyak sekolah dasar yang menjadi kelanjutan TK juga melakukan tes bisa baca, tulis dan berhitungsebagai syarat masuk; padahal pada peraturan pemerintah, seleksi dilakukan semata mata karena pertimbangan usia. Apabila usia anak sudah cukup, misalnya 7 tahun wajib meskipun ia belum pandai membaca atau menulis. Pelajaran membaca, menulis dan berhitung justru pada saat kelas satu SD dan itu menjadi tanggungjawab guru kelas 1 dan 2 . Adanya aturan masuk SD harus sudah bisa baca, tulis dan berhitung membuat para orang tua berusaha memaksa anak agar bisa baca, tulis, hitung ketika di taman kanak-kanak. Alhasil TK atau PAUD yang mengajarkan calistung semakin diminati dan sebaliknya TK yang fokus pembelajarannya pada kebutuhan perkembangan anak ditinggalkan.

Kenyataan diatas menjadi sebuah hal yang sangat membingungkan bagi guru Paud untuk mencari solusi terbaik dalam menjawab tuntutan orang tua sehingga prinsip pembelajaran di taman kanak-kanak yakni belajar sambil bermain atau bermain seraya belajar bisa dilakasanakan namun kemapuan membaca, menulis dan berhitung di taman kanak kanak dapat dimaksimalkan tanpa adanya paksaan. Dengan metode yang efektif, tidak hanya menitik tekankan anak bisa membaca dan berhitung namun diharapkan tumbuh minat dan kegemaran anak dalam membaca dan berhitung. Hal tersebut diperkuat oleh pandangan tokoh dan hasil studi model kurikulum pendidikan anak usia dini terhadap metode pengembangan kemampuan membaca menulis dan berhitung pada anak usia dini yang mempunyai beberapa pendapat sebagai berikut :

Menurut Pestalozzi cara terbaik anak mengenal konsep melalui berbagi pengalaman, yaitu dengan menghitung, mengukur, merasakan dan melakukan.

Menurut Froebel pendekatan dan cara anak melalui learning by doing, seperti explorasi, bereksperimen, demontrasi dan penugasan. Permainan anak menjadi bagian terpenting dalam pendidikan froebel. materi pendidikan nya melalui gift occupation seperti kotak kayu, dengan berbagai bentuk ( slinder, kubus, bola warna warni, balok membangun)

Menurut Montessori apa yang ia sebut sebagai periode sensitif (sensitiv periods ), yaitu munculnya masa kepekaan yang terjadi pada semua anak. Anak mengalami kepekaan yang lebih dalam dalam belajar sesuatu misalnya sensitif dalam perkembangan bahasa pada usia 1 sd 2 tahun, belajar menulis pada usia empat sampai empat tahun setengah dan membaca pada empat tahun setengah sampai lima tahun setengah. Montessori mengelompokan aktifitas belajar dan bahan bahan material kedalam tiga area, yakni practice life atau pendidikan gerak; sensory materials untuk melatih indra; dan academic materials untuk pengajaran menulis dan membaca ( kartu huruf, kartu angka, papan bilangan termasuk kertas pensil untuk kegiatan menulis ) 
Menurut Morrison (2008) dalam bukunya berjudul Dasar-Dasar Pendidikan Anak usia Dini (PAUD) menyatakan bahwa dalam 10 tahun tahun terakhir, kurikulum taman kanakkanak lebih menekankan kepada fisikmotorik,sosial, dan emosi. Dewasa ini di Amerika Serikat sendiri memasukan pengembangan akademis, seperti prabaca dan pratulis, matematika, dan pengetahuan umum; padahal sebelumnya kurang mendapat perhatian. Hal ini didorong meningkatnya kesadaran baca- tulis-hitung adalah kunci keberhasilan anak di sekolah dasar dan dalam kehidupan anak

Menurut Masnipal

dalam bukunya yang berjudul siap menjadi guru dan pengelola PAUD profesional menyatakan bahwa PAUD yang berorientasi pada baca, tulis, berhitung sebagai tujuan akan menghambat pada perkembangan totalitas anak yang seharusnya dicapai, disamping mematikan kreatifitas. Kegiatan membaca, menulis, berhitung bukanlah sesuatu yang diharamkan di PAUD, akan tetapi harus dilakukan dengan cara yang benar, metode yang menarik dan menyenangkan.

Kegiatan workshop metode FUN CALISTUNG yang dilaksanakan oleh PD IGRA pada taggal 03 juni 2012 dihadiri oleh 100 peserta dan dilaksanakan di gedung KDA Komplek KEMENAG kabupaten Cianjur menjadi latar belakang peneliti memilih metode funcalistung sebagai objek penelitian, dikarenakan setelah mengikuti workshop tersebut peneliti mendapatkan pencerahan terhadap variasi metode dan media yang disampaikan oleh ibu Onyas Rohayati sebagai pengembang metodik Funcalistung Cahaya Indonesia : Pembelajaran Menarik, Asyik dan Menyenangkan.

Setelah Metode Funcalistung diterapkan oleh beberapa guru RA di kabupaten Cianjur maka guru dapat menciptakan suasana yang menyenangkan dan menarik minat anak untuk terlibat aktif dalam setiap kegiatan pembelajaran. Tahapan-tahapan pembelajaran yang dilaksanakan senantiasa menitik tekankan pada kemampuan anak mulai dari yang termudah sampai yang tersulit. Metode bermain aktif dan atraktif serta media yang menarik membuat anak asyik dalam mengikuti setiap tahapan pembelajaran, sehingga anak tidak merasa sedang belajar membaca, menulis dan berhitung yang membosankan buat anak. Namun dari setiap permainan yang dilaksanakan dengan metode Funcalistung ini pada pelaksanaanya memberikan pengalaman belajar yang menitik tekankan pada proses bukan pada hasil, ketika proses tersebut dirasakan menyenangkan buat anak maka rangsangan positif yakni minat anak sangat meningkat untuk mempelajari materi-materi membaca dan menulis serta berhitung.

Metode Funcalistung mempersiapkan untuk anak belajar membaca permulaan, menulis permulaan dan berhitung permulaan atau prabaca, pratulis dan prahitung.

Metode Funcalistung tidak mengajarkan membaca, menulis dan berhitung tetapi merangsang, membimbing dan memfasilitasi anak yang sudah muncul minatnya agar dapat mengembangkan minat dan kegemarannya itu, dikemas melalui pembelajaran yang menarik, asyik dan menyenangkan, didukung dengan alat atau media peraga yang menarik. (Masnipal : 2014).

Metode Funcalistung di gagas dan dikembangkan oleh Onyas Rohayati (Ibu Rara) seorang guru di taman kanakkanak Cahaya Indonesia, Kota Cimahi Jawa Barat, beliau adalah seorang guru yang berpengalaman dan telah mengajar selama 20 tahun.

Gagasan lahirnya metode Funcalistung untuk menjawab kerisauan dan ketidakpuasan dirinya terhadap metode mengajar anak taman kanak- 
kanak yang selama ini ada terutama berkaitan dengan pembelajaran permulaan membaca, menulis dan berhitung. Disamping permasalahan cara atau metode mengajar yang kurang pas dengan dunia anak usia dini, Ibu Onyas Rohayati juga menyoal tentang buku atau lembar kerja siswa (LKS) dari penerbit yang kurang cocok dengan cara dan kebutuhan belajar anak usia dini. Metode belajar dan keberadaan bukubuku atau LKS ini pula yang mendorong beliau untuk menemukan metode yang sesuai dengan dunia dan perkembangan anak usia dini.

Pola pemikiran tradisional yang menekankan pada kemampuan logika (matematika) dan bahasa memang sudah mengakar dengan kuat pada diri setiap guru dalam menjalankan proses belajar. Bahkan hasil penelitian yang dilakukan oleh Yayasan Insan Kancil (Harian Kompas, 13 Oktober 2008) pendidikan taman kanak-kanak saat ini cenderung mengambil porsi sekolah dasar, sekitar 99 persen. Taman kanak-kanak mengajarkan membaca, menulis dan berhitung. Artinya pendidikan taman kanak-kanak telah menekankan kepada kecerdasan akademik, tanpa memperhatikan apakah penyampaiannya ramah otak atau tidak (Agustin : 2011).

\section{Metode Funcalistung}

1. Pengertian Pelatihan Metode Funcalistung

Pelatihan metode Funcalistung merupakan kegiatan pelatihan yang membantu guru-guru PAUD agar dapat mempersiapkan anak agar dapat belajar membaca permulaan, menulis permulaan dan menghitung permulaan secara asyik dan menyenangkan.

2. Latar Belakang Lahirnya Metode Funcalistung

Metode funcalistung digagas dan dikembangkan oleh Onyas Rohayati (Ibu Rara), seorang guru PAUD berpengalaman lebih dari 20 tahun sebagai guru di taman kanak-kanak Cahaya Indonesia, kota Cimahi, Jawa Barat.Ibu Rara adalah lulusan PGTK ; semacam kursus satu tahun di PGTK yayasan bersekolah pada ibu sebagai salah satu lembaga tertua di Indonesia yang pertama memenuhi mendidik calon guru taman kanakkanak, dimulai tahun 1951 di Bandung (Masnipal : 2013).Gagasan lahirnya metode funcalistung untuk menjawab kerisauan dan ketidakpuasan dirinya terhadap metode mengajar anak taman kanakkanak yang selama ini ada, terutama berkaitan dengan pembelajaran permulaan membaca, menulis dan berhitung. Disuatu sisi pemerintah melarang pembelajaran membaca, menulis dan berhitung (calistung) di TK/RA atau sejenisnya, akan tetapi di sisi lain, para orang tua menghendaki anak agar anak diajar calistung, sebab ketika masuk SD anak di tes calistung. Celakanya, keinginan orang tua ini dijawab oleh guru dengan mengajarkan calistung mentah-mentah, dengan cara jejal dan cekok.Disamping permasalahan cara atau metode mengajar yang kurang pas dengan dunia anak usia dini, Ibu Rara juga menyoal tentang buku atau LKS dari penerbit yang kurang cocok dengan cara dan kebutuhan belajar anak usia dini.

3. Pengembangan Metodik

Untuk menjawab kerisauannya, pada tahun 2004 Ibu Rara mulai mempersiapkan bahan-bahan, alat peraga yang dibuat khusus dan langkah-langkah pembelajaran. Selanjutnya beliau menyampaikan konsep dan gagasannya kepada guruguru tentang cara mengajar yang mampu membuat anak tetap merasa senang, nyaman dan enjoy dalam belajar, termasuk dalam mengajarkan persiapan permulaan membaca, menulis dan berhitung. 
Tahap berikutnya Ibu Rara mulai mempraktikan metode awalnya disebut metode (Cahaya Indonesia) langsung kepada siswa dihadapan guru-gurunya. Masukan dari guruguru yang menerapkan metode ini dilapangan, terus memicu Ibu Rara untuk menyempurnakannya. Keberhasilan metode ini akhirnya membuat banyak guru yang ingin mempelajarinya.

Banyaknya permintaan guru-guru PAUD, sejak tahun 2009 Ibu Rara menyusun lembar kerja siswa (3 buku untuk TK A dan 5 buku untuk TK B). buku kerja siswa bertujuan membantu anak-anak yang mulai berkembang, terutama pada aspek motorik, bahasa dan kognitif. Anakanak yang mulai mencoret misalnya bisa disalurkan melalui LKS agar perkembangan motorik halusnya terus berkembang menjadi lebih lentur dan gerakan mata-tangan terjadi lebih terkoordinasi.

Semakin banyaknya guru PAUD yang mempelajari metode funcalistung, mulai September 2012 mulai diselenggarakan pelatihan terbuka. Hingga sekarang, guru PAUD yang telah mengikuti pelatihan ini lebih dari 2.000 orang, itupun baru di beberapa tempat, seperti Bandung, Kab. Bandung, Bandung Barat, Garut, Cianjur, Sukabumi, Majalengka dan beberapa daerah dari Sumatera.

4. Konsep Dasar dan Pengertian

Metode funcalistung merupakan cara atau strategi membelajarkan anak usia dini secara total, dikemas secara menyenangkan melalui pembelajaran yang menarik dan disajikan dalam proses yang asyik. 2 komponen dasar penggunaan metode funcalistung, yaitu membelajarkan anak secara total dan disajikan oleh guru secara total. Oleh karena dua dasar inilah metode funcalistung juga dikenal sebagai pembelajaran total atau total learning membelajarkan anak secara total berarti :

1) Mengembangkan seluruh aspek perkembangan lainnya. Aspekaspek perkembangan meliputi :

- Kognitif yaitu kemampuan berpikir rasional, berpikir (divergen) (kreativitas) dan problem solving.

- Fisik atau motorik yaitu motorik kasar, motorik halus dan koordinasi.

- Komunikasi yaitu menerima bahasa, menyampaikan dan etika berkomunikasi.

- Emosi dan sosial, yaitu menumbuhkan perasaan terhadap diri sendiri, membangun perasaab terhadap orang lain dan perasaan seni.

- Moral, yaitu karakter yang sudah melekat dalam jati diri bangsa dan karakter yang perlu dibangun sesuai tuntutan zaman.

- Ketuhanan, yaitu nilai-nilai ketuhanan, hubungan dengan sang pencipta dan hubungan antar makhluk.

2) Semua aspek diikat dalam satu misi pembelajaran hari itu, dikembangkan sesuai dengan minat anak. Minat itu dijadikan tema hari itu.

3) Pembelajaran dikemas dan disajikan dengan menarik (minat anak) disampaikan melalui proses yang asyik bagi anak : dalam suasana dan iklim bermain belajar yang sengaja diciptakan secara menyenangkan.

4) Anak terlibat secara total mengikuti alur pembelajaran dari waktu ke waktu dengan melibatkan seluruh panca indera pembelajaran diikuti dengan cara melihat, mendengar, merasakan dan melakukan. 
Disajikan oleh guru secara total (all out) mengandung makna bahwa :

a. Guru tampil total (all out) berarti :

- Pembelajaran sudah direncanakan dan dipersiapkan secara total dan matang paling tidak sehari sebelumnya.

- Dengan ide atau gagasan apa yang hari itu akan disajikan dengan bermakna bagi anak.

- Pola interaksi dan setting kelas (jika pembelajaran kelompok) yang sesuai dengan tema atau materi hari itu.

- Dilaksanakan oleh guru melalui pola permainan yang sistematik, step by step.

b. Terjalin kontak penuh (full contact) dengan seluruh siswa selama proses pembelajaran.

c. Guru menggerakan segenap kemampuan dan keterampilannya semaksimal mungkin untuk menciptakan pembelajaran yang asyik, menarik, menyenangkan dan bermakna.

d. Pembelajaran harus melibatkan seluruh perkembangan anak, mulai dari berpikir aktif, bergerak melakukan, bersuara, bernyanyi, berirama dilakukan bersama-sama (kontak sosial) dan memberikan kesempatan untuk setiap anak berkembang dalam kemandirian (emosional).

e. Dilengkapi dengan sumber belajar konkrit yang kaya dan bervariasi.

f. Dilengkapi dengan alat peraga khusus, dan menggunakan white board.

g. Menggunakan alat musik (organ, gitar) dan pembelajarannya untuk menggiring proses pembelajaran secara penuh, awal hingga akhir.

5. Berorientasi Kepada Minat dan Gemar Bukan Bisa

Metodik funcalistung bukanlah cara cepat mengajarkan membaca, menulis dan berhitung kepada anak, metode funcalistung tidak setuju dengan cara mengajar membaca, menulis dan berhitung dengan jejal dan cekok. Metode funcalistung tidak berorientasi kepada anak bisa baca, tulis dan hitung, tetapi menumbuhkan minat dan kegemaran anak terhadap buku, bahwa didalam buku ada banyak cerita yang menarik

6. Prinsip-prinsip Dasar

Guru yang menggunakan metode funcalistung, berpegang kepada prinsip- prinsip berikut :

a. Anak usia dini harus dianggap sebagai manusia yang mulai tumbuh dan berkembang. Pertumbuhan dan perkembangan itu meliputi seluruh aspek yaitu kognitif, fisik / motorik, bahasa, sosial dan emosional, moral dan agama, berkembang secara bersamaan mengikuti usianya.

b. Setiap anak usia dini berusaha sekuat mungkin untuk memnuhi tugas perkembangan agar mencapai kematangan dari setiap aspek melalui semua aktivitasnya, bergerak dan bereksplorasi secara aktif.

c. Anak usia dini haus akan pengalaman baru, menyukai benda konkrit.

d. Belajar dan bermain merupakan satu kesatuan utuh tak terpisahkan : bermain adalah inti (corestone) dalam pendidikan anak usia dini.

7. Dasar Pertimbangan dan Teori Funcalistung

a. Tuntutan Orang Tua Dalam sepuluh tahun terakhir, keinginan masyarakat agar anak mereka terutama kelompok B 
taman kanak-kanak (usia 4-6 tahun) yang satu tahun ke depan akan masuk sekolah dasar (SD) agar dibekali dasar, membaca, menulis dan kegiatan menghitung semakin meningkat. Ini disebabkan dari waktu ke waktu semakin banyak sekolah dasar (SD) yang melakukan seleksi terhadap kemampuan membaca, menulis dan berhitung sebagai syarat masuk, meskipun pemerintah melarang. Banyak SD yang terang-terangan melakukan tes membaca, menulis dan berhitung sebelum masuk sekolah. Kondisi itu membuat para orang tua "mendesak" para guru taman kanak-kanak memberikan pembelajaran calistung. Bahkan sampai banyak orang tua yang memilih memindahkan anaknya ke sekolah lain jika di TK tersebut tidak memberikan calistung. Kondisi itu juga membuat para guru TK resah kareba kehilangan murid.

Cara lain yang ditempuh orang tua jika di TK tidak diberikan pembelajaran calistung adalah dengan memanggil guru privat ke rumah. Cara privat jelas memasung anak dengan jejal dan cekok sehingga menjadi beban bagi anak. Guru privat biasanya hanya tertuju anak hasrus bisa baca dan tulis, tidak memperhatikan kebutuhan perkembangan dan kesiapan anak.

b. Dilematis Guru

Dari beberapa kali pelatihan Funcalistung di beberapa daerah diketahui hampir semua guru bingung soal memberikan tau tidak memberikan calistung.

Hadirnya Funcalistung seperti membawa angin segar bagi guru, baik yang memberikan calistung dan yang tidak memberikan dari pelatihan funcalistung mereka pun menyadari mengapa calistung dilarang dan bagaimana cara yang benar dalam membelajaran calistung.

Guru yang akan menggunakan metode funcalistung adalah guru yang telah mengikuti pelatihan funcalistung terlebih dahulu, paling tidak satu kali 4 jam pelatihan dirancang untuk memberi contoh pada pelaksanaan secara teknis.

c. Dari Sudut Perkembangan Anak Dalam buku "Siap menjadi guru dan pengelola PAUD professional" (Masnipal : 2013) insting terhadap minat membaca (buku) dan menulis sebenarnya telah diawali pada umur 15 bulan, yaitu membolak balikan halaman buku dan munculnya kegemaran mencoret-coret dengan pensil atau krayon.

Pada umur 22 bulan, gemar coretcoret, pegang pensil dengan menggenggam. Sudah bisa menceritakan rangkaian gambar sederhana. Pada umur 27 bulan kemampuan anak dalam membaca dan menulis terus meningkat. Anak sudah bisa menceritakan hasil coret-coretannya dan membaca pura-pura dengan melihat gambar buku.

Pada umur 30 bulan, anak senang mendengar cerita-cerita dari buku-buku bergambar yang dibaca ibunya. Umur 34 bulan, bisa menceritakan isi gambar : tertarik bermain konstruktif (lego/lasi). Umur 3 tahun, anak berfantasi pura-pura baca yang ceritanya ia buat sendiri, gemar menggunting (pengembangan motorik harus menadi dasar menulis). Pada umur 3,5 tahun bisa menceritakan dengan benar cerita dalam buku bergambar, meskipun belum pernah diajarkan membaca, usia 4 tahun anak 
sudah bisa membaca sendiri tanpa bantuan, meskipun terbata-bata.

\section{Metode Penelitian}

Lokasi penelitian ini dilakukan di Taman Kanak-Kanak Cahaya Indonesia, Cimahi Jawa Barat, Subjek penelitian yang dimaksudkan mengarah kepada aspek yang menjadi salah satu asumsi sasaran penelitian sebagai pelaku dalam penelitian ini adalah kepala sekolah, guru kelompok B 1 orang, orang tua 3 orang. Penelitian ini akan dilaksanakan selama 6 bulan terhitung bulan juli sampai dengan bulan januari ditambah 1 Bulan Penelitian pendahuluan. Penelitian ini merupakan penelitian deskriptif dengan menggunakan pendekatan kualitatif.. Dalam melakukan penelitian ini penulis menggunakan teknik pengumpulan data Pengamatan berperan serta (participation observation). dan wawancara. Jenis metode pengamatan partisipatif dalam penelitian ini adalah metode pengamatan partisipatif moderat (moderate participation), maksudnya adalah pengamatan yang dilakukan dengan mengamati apa yang dikerjakan orang, mendengar apa yang diucapkan dan berpartisipasi dalam aktivitas mereka secara seimbang, yakni antara menjadi orang dalam dan orang luar. Data yang akan dikumpulkan dengan metode pengamatan ini adalah sebagai berikut :

1. Cara efektif penggunaan Metodik Funcalistung untuk menumbuhkan minat dan kegemaran mengenal huruf dan angka pada kelompok B TK Cahaya Indonesia Cimahi

2. Peran guru dalam menggunakan Metodik Funcalistung yang efektif untuk menumbuhkan minat dan kegemaran mengenal huruf dan angka di kelompok B TK Cahaya Indonesia Cimahi

3. Efektifitas penggunaan alat dan media dalam Metodik Funcalistung sehingga menumbuhkan minat dan kegemaran mengenal huruf dan angka di kelompok B TK Cahaya Indonesia Cimahi .

4. Suasana kegiatan belajar mengajar ( KBM ) yang tercipta ketika menggunakan metode Funcalistung dalam menumbuhkan minat dan kegemaran mengenal huruf dan angka di kelompok B TK Cahaya Indonesia Cimahi .

\section{Hasil Penelitian Dan Pembahasan}

Jawaban dari 4 pertanyaan penelitian yang diajukan memberikan kontribusi untuk mengetahui gambaran tentang efektifitas metode Funcalistung dalam menumbuhkan minat dan kegemaran mengenal huruf dan angka di kelompok B TK Cahaya Indonesia Cimahi.

Pertama, cara efektif penggunaan metode Funcalistung dalam menumbuhkan minat dan kegemaran mengenal huruf dan angka sangat dipengaruhi oleh strategi khusus didasari dengan sebuah pemahaman tentang karakteristik anak usia dini yang diantaranya adalah memiliki rasa ingin tahu yang besar dan masa paling potensial untuk belajar (Hartati,2005). Guru pun harus memperhatikan titik kritis yang diantaranya anak membutuhkan latihan dan rutinitas, membutuhkan pengalaman langsung serta melakukan kegiatan bermain yang merupakan dunia masa kanak-kanak (Kartadinata,2003). Sehingga berdasarkan hasil observasi dan wawancara peneliti terhadap pelaksanaan metode Funcalistung di kelompok B Tk Cahaya Indonesia strategi penerapan metodik ini sangat memperhatikan hal-hal diatas karna melalui proses penyampaian materi dengan diawali apresepsi secara individual dan klasikal serta pengelolaan tahapan materi yang dilakukan secara bertahap dari yang termudah sampai yang tersulit sesuai dengan tingkat 
pencapaian perkembangan anak usia 5 sampai dengan 6 tahun dalam hal standar kompetensi kogniti yang tersurat di dalam peraturan mentri pendidikan nasional no 58 tahun tahun 2009 yakni mengenal konsep lambang bilangan dan huruf.

Pemberian motivasi berupa berbagai macam hadiah yang disukai anak dan stimulasi melalui metode pembelajaran yang bervariatif menumbuhkan minat dan kegemaran anak dalam mengenal huruf dan angka.

Penggunaan metodik Funcalistung dilaksanakan dengan menitik tekankan pada proses menumbuhkan minat dan kegemaran dalam mengenal huruf dan angka yang dilaksanakan dengan strategi belajar yang membuat anak mengikuti pembelajaran dengan asyik dan menyenangkan maka anak tidak merasa terpaksa untuk mengikuti kegiatan prabaca dan prahitung. Kemampuan membaca dan berhitung menjadi hasil akhir yang dapat dikembangkan secara maksimal dan sesuia dengan harapan dan tujuan sebagian besar orang tua murid yang menyekolahkan anaknya di TK Cahaya Indonesia.hal ini sesuai dengan apa yang dikemukakan oleh Morrison (2008) dalam bukunya DasarDasar Pendidikan Anak Usia Dini (PAUD) menyatakan bahwa dalam 10 tahun terakhir, kurikulum taman kanakkanak lebih menekankan kepada fisikmotorik, sosial, dan emosi. Dewasa ini di Amerika Serikat sendiri memasukan pengembangan akademis, seperti prabaca, praulis, matematika dan pengetahuan umum; padahal sebelumnya kurang mendpat perhatian. Hal ini didorong meningkatkan kesadaran baca-tulis-berhitung adalah kunci keberhasilan anak di sekolah dasar dan dalam kehidupan anak. Diperkuat oleh pendapat Masnipal (2013) dalam bukunya yang berjudul siap menjadi guru dan pengelola PAUD profesional menyatakan bahwa PAUD yang berorientasi pada baca, tulis, berhitung sebagai tujuan akan menghambat pada perkembangan totalitas anak yang seharusnya dicapai, disamping mematikan kreatifitas. Kegiatan membaca, menulis, berhitung bukanlah sesuatu yang diharamkan di PAUD, akan tetapi harus dilakukan dengan cara yang benar, metode yang menarik dan menyenangkan.

Kedua, peran guru dalam menggunakan metode Funcalistung dalam menumbuhkan minat dan kegemaran mengenal huruf dan angka di kelompok B sangat dipengaruhi oleh sejauhmana guru dapat merancang sebuah perencanaan pembelajaran mulai dari program tahunan, program semester, program mingguan dan program harian khusunya dalam kompetensi dasar kognitif, sesuai dengan faktor-faktor yang mempengaruhi perkembangan kognitif (Yuliani Nurani Sujiono, dkk, 2008) yakni : faktor keturunan, faktor lingkungan, faktor kematangan, faktor pembentukan, faktor minat dan bakat, faktor kebebasan .

Pembawaan dan penampilan guru sangat mempengaruhi dalam mengguakan metode Funcalistung dalam menumbuhkan minat dan kegemaran mengenal huruf dan angka, dikarenakan sosok guru yang Penampilan dengan menggunaan pakaian yang serasi dipandang mata, bersih, rapih, sopan serta senantiasa menampilkan mimik muka yang cerah , ceria, penuh kehangatan, sabar dan bersahaja sehingga serta berpembawaan penuh semangat dan antusias, expresif dalam setiap kegiatan pembelajara akan menciptakan kedekatan dan menjadikan guru tersebut sebagai idola sehingga apapun yang disampaikan oleh guru tersebut akan diikuti oleh anak dan meninggalkan kesan yang bermakna.

Pengelolaan kelas dalam penggunaan strategi pembelajaran, pengkondisian anak, penguasaan materi dan metode pembelajaran serta kemampuan menseting kelas juga melakukan proses 
evaluasi terhadap perkembangan anak merupakan hal yang mempengaruhi efektifitas penggunaan metode Funcalistung.

Ketiga, Penggunaan media yang menarik dapat dibuat dari barang bekas, bahanya mudah dan murah serta dapat memanfaatkan lingkungan sekitar seperti menghitung daun, batu dan lain sebagainya.bentuknya harus penuh warna supaya menarik dan dapat dimainkan langsung oleh anak . penataan dan penempatan yang sesuia juga penggunaan metode pembelajaran yang variatif dan atraktif membuat peserta didik bersemangat dan antusias dalam mengikuti berbagai macam kegiatan pembelajaran.

Hal ini sesuai dengan pendapat Luluk Asmawati, 2014 dalam bukunya berjudul " perencanaan pembelajaran PAUD" bahwa media pembelajaran adalah media grafis, tiga dimensi, media proyeksi, dan pemanfaatan lingkungan sebagai sumber belajar. Manfaat media pembelajaran, yaitu (1) materi pembelajaran akan lebih jelas maknanya sehingga dapat lebih dipahami oleh para siswa, dan siswa menguasai tujuan pembelajaran dengan lebih baik, (2) metode mengajar akan lebih bervariasi, (3)aktivitas siswa dapat lebih terintegrasi melalui pengamatan, melakukan, mendemontrasikan (seluruh indra berfungsi), (4) materi pembelajaran menjadi lebih menarik dan kongkrit. Media bermain berpengaruh terhadap kesenangan anak, maka bentuk dan penampilanya harus menarik.

Keempat, suasana kegiatan belajar mengajar yang harus diciptakan dalam mengefektifkan penggunakan metode Funcalistung dalam menumbuhkan minat dan kegemaran sangat dipengaruhi oleh seting kelas, tekhnik pengkondisian anak, kenyamanan serta cara guru dalam menghidupkan suasana di kelas dengan melaksanakan strategi pembelajaran yang variatif dan atraktif seperti perlombaan dan bemain peran dengan melibatkan seluruh anak, sehingga menciptakan suasana yang asyik dan menyenangkan. Strategi dalam menerapkan ketertiban dan ketenangan di dalam kelas harus dilakukan sejak anak masuk pada tahun ajaran baru dengan menerapkan peraturan dan tata tertib sekolah yang sudah dirancang sedemikian rupa secara terus menerus dengan senantiasa memberikan penghargaan baik berupa pujian atau benda benda yang menarik buat anak yang biasa menjaga ketertiban dan ketenangan di dalam kelas. Atau memilih salah satu anak untuk menjadi ketua kelas dan ketua kelompok untuk berlatih bertanggung jawab saling mengingatkan antar teman nya dalam menjaga ketertiban dan kenyamanan sekolah atau kelas.

\section{Simpulan Dan Rekomendasi}

\section{Simpulan}

Dari penelitian dan pembahasan tentang efektifitas metode Funcalistung menumbuhkan minat dan kegemaran mengenal huruf dan angka di kelompok B TK Cahaya Indonesia Cimahi, maka dapat diambil beberapa kesimpulan :

1. Cara efektif penggunaan metode Funcalistung adalah ditentukan oleh perencanaan strategi khusus diawali dengan memberikan pemahaman kepada orangtua murid tentang esensi pendidikan anak usia dini terutama pada materi pengembangan kognitif dan keaksaraan . Tidak hanya menitiktekankan pada hasil bahwa anak hanya bisa membaca dan berhitung namun bekerjasama menciptakan proses pembelajaran di sekolah atau di rumah dengan asyik dan menyenangkan sehingga anak-anak tidak merasa terpaksa dan tertekan dalan mengikuti pembelajaran tetapi akan timbul kegemaran dalam membaca dan berhitung serta minat untuk 
mengenal huruf dan angka meningkat. Hal ini diperkuat dengan prosedur pelaksanaan kegiatan yang terencana baik dalam hal pengelolaan materi, pengkondisian kelas, penggunaan metode yang bervariasi dan menyenangkan, penggunaan media yang menarik, pemberian motivasi dengan reward yang bervariasi serta proses evaluasi sebagai titik tolak pengukuran keberhasilan metode dan perkembangan kemampuan peserta didik khuusnya dalam materi mengenal huruf dan angka.

2. Guru merupakan Faktor yang penting dalam mengefektifkan metode Funcalistung dalam menumbuhkan minat dan kegemaran mengenal huruf dan angka. Motivasi guru dalam mengajar akan meningkat dimulai dengan merancang sebuah strategi belajar mengajar, menyiapkan sebuah perencanaan pembelajaran baik tahunan, semesteran, mingguan dan harian. Membuat media dan mengatur tekhnik penggunaan dan penempatan di kelas. Melaksanakan pengelolaan kelas dengan melaksanakan pembelajaran dari mulai pembukaan di pagi hari sampai dengan penutupan di siang hari dengan proses apermasi, penyampaian materi yang jelas, menstimulasi kreatifitas anak didik, pemberian reaword, peduli terhadap anak didik secara individual dan jeli serta menghargai terhadap kebutuhan , kelebihan dan kekurangan anak didik . menjadi sahabat anak dengan senantiasa memperhatikan penampilan, ekspresi, mimik wajah, pembawaan yang hangat dan senantiasa tersenyum ceria dan bersemangat dalam mengajar sehingga peserta didik akan merasa nyaman berada dekat ibu guru dan pembelajaran akan lebih bermakna dan memberi kesan untuk peserta didik.

3. Ketersediaan media yang sesuai dengan tujuan pembelajaran akan membuat metodik Funcalistung lebih efektif apabila media tersebut mudah untuk dibuat, terbuat dari bahan yang mudah ditemukan dan murah meriah, terdiri dari berbagai macam bentuk dan warna yang menarik, bisa dimainkan oleh peserta didik, tidak berbahaya dan membuat ibu guru lebih kreatif

4. Suasana pembelajaran yang menyenangkan akan lebih mengefektifkan metode Funcalistung dalam menumbuhkan minat dan kegemaran mengenal huruf dan angka. Dengan cara melakukan seting kelas yang rapih , bersih, tertib dan nyaman menciptakan suasana yang tenang dan terarah serta aktivitas anak dalam mengikuti pembelajaran terkendali dan terkondisikan dengan baik. Penggunaan alat musik sebagai pengiring atau pembuka akan menambah keceriaan dalam mengikuti pembelajaran. suasana pembelajaran dengan menggunakan tekhnik perlombaan dan bermain peran akan meningkatkan minat dan kegemaran anak serta terliibat aktif dalam mengikuti pembelajaran dan suasana kelas pun akan terasa hidup dan bersemangat, anak didik terlihat asyik dan senang dalam mengikuti pembelajaran

\section{Rekomendasi}

Berkaitan dengan hasil penelitian, maka dalam bagian ini dikemukakan beberapa rekomendasi

1. Untuk Guru TK, RA dan Kober

Supaya proses penggunaan metoda Funalistung lebih efektif dalam menumbuhkan minat dan kegemaran mengenal huruf dan 
angka, maka guru dituntut untuk melakukan hal hal sebagai berikut :

a. Memberikan pemahaman kepada orang tua tentang pentingnya melakukan proses stimulasi terhadap minat dan kegemaran anak didik dalam prabaca dan prahitung dengan menggunakan metode yang asyik dan menyenangkan. Tidak hanya menitiktekankan pada kemampuan untuk bisa membaca dan menulis tetapi senang dan gemar membaca dan berhitung.

b. Ikut serta dalam berbagai pelatihan Funcalistung dan membahas lebih dalam tentang kunci kunci keberhasilan penggunaan metodik ini.

c. Menerapkan metodik Funcalistung dengan memperhatikan strategi pembelajaran, peran guru, penggunaan media, pengkondisian kelas dan melakukan evaluasi.

d. Dengan latar pendidikan yang variatif, sebaiknya guru PAUD baik kober, Tk ataupun RA memaksimalkan penggalian potensi dalam diri masing masing baik dalam hal memperhatikan performance meningkatkan wawasan dan kemampuan dalam hal penguasaan kurikulum, strategi belajar mengajar, kreatif dan inovatif dalam menggunakan metode dan media pengajaran. Fokus dan konsisten terhadap perkembangan kompetensi anak didik.

e. Mengaplikasikan metode Funcalistung dengan konsisten dan berkesinambungan.serta mengevaluasi proses penggunaan metodik ini supaya lebih efektif dalam menumbuhkan minat dan kegemaran dalam bidang kognitif guna mempersiapkan kemampuan membaca dan berhitung peserta didik khusunya di kelompok B.

2. Untuk Tim dan Yayasan Cahaya Cipta Kreativitas :

a. Untuk mengadakan pelatihan selama 2 hari supaya peserta lebih memahami maksimal.

b. Mengadakan program magang selama sepekan supaya guru akan lebih memahami pelaksanaan penggunaan dan menguasainya

c. Hendaknya pelatihan ini dapat dilaksanakan diseluruh Indonesia.

d. Merintis dan mendirikan cabang TK Cahaya Indonesia di setiap kabupaten agar proses studi banding bagi guru guru akan lebih mudah dan lebih dekat.

e. Bekerja sama dengan lembaga TK.RA atau Kober secara formal untuk menerapkan metodik Funcalistung dengan konsisten melakukan pembinaan atau bimbingan berkala dan visitasi ke sekolah sekolah tersebut.

\section{Daftar Pustaka}

Andi Prastowo. (2012). Metode Penelitian Kualitatif. Jakarta: ArRuzz Media Cet. Ke-2.

Aulia. (2012). Revolusi Pembuat Anak Candu Membaca Flash Book. Jogjakarta.

Badru Zaman dkk. (2008). Media dan Sumber Belajar TK Universitas Terbuka.Jakarta.

Buchari Alma. (2012).Guru Profesional.Alfabeta. Bandung. 
Djam'an Satari dkk. (2008). Profesi Keguruan. Universitas Terbuka.Jakarta.

Fadhal Ar Bafadal dan Kawankawan, (2002). tafsir Al-Qur'an. Surabaya.

George S. Morrison. (2012). DasarDasar Pendidikan Anak Usia Dini (PAUD). Jakarta.

Lexy J. Moleong. (2013). Metodologi Penelitian Kualitatif, Bandung: Rosda Karya, Cet. Ke31.

Imam Wahyudi. (2012). Mengajar Profesionalisme Guru. PT. Rosda Karya. Jakarta.

Luluk Asmawati. (2011) Pengelolaan Kegiatan Pengembangan Anak Usia Dini. Universitas. Jakarta.

Masnipal. (2013). Siap menjadi guru dan pengelolaan PAUD Profesional. PT. Elex Media Komputindor.Jakarta.

Masitoh. (2008). Strategi Pembelajaran TK. Universitas Terbuka. Jakarta.

Moeslichatoen. (2004). Metode Pengajaran. PT. Rineka Cipta. Jakarta.

Moh. Uzer Uman. (2013). Menjadi Guru Profesional. PT. Remaja Rosda Karya. Bandung.

M. Solehudin dkk. (2009). Pembaharuan Pendidikan TK. Universitas Terbuka.
Jakarta.

M. Toha Anggoro dkk. (2011). Metode Penelitian. Universitas Terbuka. Jakarta.

Mubiar Agustin. (2011). Permasalahan Belajar dan Inovasi Pembelajaran. PT Refika Aditama Bandung.

Muhibbin Syah. (2005). Psikologi Pendidikan. Bandung. Rosda Karya, Cet. Ke 11.

Nurbiana Dhieni dkk. (2008). Metode Pengembangan Bahasa. Universitas Terbuka.Jakarta.

Siti Aisyah dkk (2009).Perkembangan Konsep Dasar AUD.Universitas Terbuka Jakarta

Soegiono. (2008). Metode Penelitian Pendidikan. Alfabeta.Bandung.

Soegeng Santoso. (2008). Dasardasar Pendidikan TK. Universitas Terbuka. Jakarta.

Sugiyono. (2012). Metode Penelitian Kualitatif, Kuantitatif dan R \& D. PT. Alfabeta. Bandung.

Widarmi D Wijana dkk. (2011). Kurikulum Pendidikan Anak Usia Dini. Universitas Terbuka. Jakarta.

Yuliani nurani (2008). Metode pengembangan Kogniift. Universitas Terbuka. Jakarta. 